\title{
Language as a "mirror of nature"
}

\author{
Jaakko Hintikka \\ Dept. of Philosophy, Boston University, \\ 745 Commonwealth Ave, Boston, MA 02215, USA \\ e-mail: hintikka@bu.edu
}

\begin{abstract}
How does language represent ("mirror") the world it can be used to talk about? Or does it? A negative answer is maintained by one of the main traditions in language theory that includes Frege, Wittgenstein, Heidegger, Quine and Rorty. A test case is offered by the question whether the critical "mirroring" relations, especially the notion of truth, are themselves expressible in language. Tarski's negative thesis seemed to close the issue, but dramatic recent developments have decided the issue in favour of the expressibility of truth. At the same time, the "mirroring" relations are not natural ones, but constituted by rule-governed human activities à la Wittgenstein's language games. These relations are nevertheless objective, because they depend only on the rules of these "games", not on the idiosyncrasies of the players. It also turns out that the "truth games" for a language are the same as the language games that give it its meaning in the first place. Thus truth and meaning are intrinsically intertwined.
\end{abstract}

In this day and age, the different main approaches to language - semiotic, linguistic, logical, and psychological - have unfortunately little to do with each other. It is therefore in order, is seems to me, to take this opportunity to report to you some interesting recent and ongoing developments in logical theory, philosophy of language, and formal semantics in the hope that they might illuminate the issues dealt with in the other approaches. As a focal point I have chosen the idea of language as "a mirror of nature" in spite of the fact - or because of it - that this slogan is ambiguous. It is easy to see what a theory would be like that maintained that language is a mirror of the 
world. Wittgenstein's so-called picture theory is probably the most fully worked-out example of such a view. But it is far less clear what is meant - or even what can be meant - by the fashionable denials of the view that language somehow corresponds to or "mirrors" nature. Without claiming exhaustiveness, one can perhaps distinguish the following three interrelated ingredients of this syndrome of ideas.

(1) The essence of language is not representation, but interpersonal communication, having such different forms as commanding, inquiring, promising, gossiping, praying, etc. All these have played a role in philosophers' and other scholars' theories. Wittgenstein had a much longer list of different uses of language, and his first example of a language-game was a sequence of commands. For L. E. J. Brouwer the main function of language was "Willensübertragung". I can very well understand the temptation to think that questions and answers, rather than statements, are the basic mode of language use. Indeed, I have tried to epitomise my interrogative theory of knowledge-seeking in the slogan "inquiry as inquiry". Some scholars have seen in gossiping the context of the genesis of human language, and Aristotle already mentioned prayers as an example of utterances that are neither true nor false.

(2) A closely related thesis claims that language is an essentially social phenomenon, that it is conceptually impossible to think of a language without a language community. A widespread interpretation attributes such a view to Ludwig Wittgenstein. According to such an allegedly Wittgensteinian view language is a role-governed human activity whose rules can be created and enforced only by a language community.

(3) A much deeper philosophical view holds that it is in principle impossible to speak consistently of the semantic relationships between language and reality. As test case of such relationships is the notion of truth, that is to say, the relation of a true sentence to the fact that makes it true. This relation is presumably what is meant by the notion of mirroring in the title of this essay.

Admittedly, we can define the notion of truth, as Tarski showed in his classical monograph of 1935, for explicitly formulated logical languages. But, as Tarski is supposed also have shown, this can happen only by means of a richer metalanguage. Now there does not exist any richer metalanguage over and above our actual working language, 
Tarski's "colloquial language". Hence the general unrestricted notion of truth cannot be used in an colloquial language without running into contradictions. As I once put it, for a serious theorist of our actual working language "true" is a four-letter word to be avoided in polite philosophical discourse. And if so, all talk about our actual language mirroring actual reality must in the last (non-Freudean) analysis be little better than nonsense. The only alternative would be to postulate an altogether different hermeneutical technique of approaching the fundamental language-world relations. It is no accident that for Heidegger truth is not correspondence but "Erschlossenheit".

The news I have to report to you is that all these three ways of rejecting the idea of correspondence between language and the world are either demonstrably wrong or without the support they are generally though to have. I will first deal with the first two. Within the scope of a single essay, I cannot deal adequately with all the systematical issues involved; therefore I will approach them ad hoc, or rather in terms of an experimentum crucis. This experiment is offered to us by the philosophy of language of Ludwig Wittgenstein, who is generally thought of as the main representative of the views (1) and (2). I will begin with the second. Speaking historically, not all commentators have accepted the interpretation according to which for Wittgenstein language is an intrinsically (conceptually) social phenomenon. There used to be controversies as to whether an isolated human being not living in any language community could be said to have a language. As if to illustrate this very problem, Daniel Defoe has constructed for us the scenario of Robinson Crusoe on his desert island before the arrival of Friday. The defenders of the orthodox interpretation of Wittgenstein must maintain that in a strict philosophical sense Robinson Crusoe could not have a language.

Now this interpretational question has been answered by no lesser of a commentator than Ludwig Wittgenstein himself. In his unpublished writings he repeatedly discusses the question whether an isolated individual outside all language communities could have a language. Wittgenstein even uses the very same example of Robinson Crusoe. And his point is completely unequivocal. Yes, according to him Robinson Crusoe could have a language, provided that he behaves vis-à-vis his own utterances in a certain rule-governed way, so that a hidden observer could, for instance, use his monological statements to predict his behaviour. No language community is needed to 
enforce those rules. In this sense, for Wittgenstein language is not an intrinsically social phenomenon.

This is an interesting result. The sociolinguistic speculations of people like David Bloor and Peter Winch may or may be argued for, as far as this essay goes, but they have nothing to do with Wittgenstein's ideas. Their defenders' attempts to hang on Wittgenstein's coat-tails are therefore little short of ridiculous.

But if this was Wittgenstein's view, why did he not say so in his main work, the Philosophical Investigations? Well, he does say so, but without using the example of Robinson Crusoe. This is because he had meanwhile become interested in the processes of a language acquisition as providing especially important clues to its semantics. And from this point of view, Defoe's story is no longer an apt illustration, for Crusoe had learned his language before landing on his island. Unfortunately, Wittgenstein did not come up with a better parable to illustrate his updated view. But this does not mean that Wittgenstein changed his views on the social - or, rather, public - character of language in the least.

But didn't Wittgenstein argue in so many words against the possibility of a private language? Yes, but what did he mean by "private"? This word has two uses, and figures in two different contrasts. The private-public contrast can be roughly equivalent to the internalexternal contrast, that is, to the contrast between what is accessible only to oneself and what is accessible to others. This is the sense in which Wittgenstein denied the possibility of a private language. Robinson Crusoe's language behaviour must in principle be observable by others.

But "private language" can also mean a monological language, that is, a language that is not shared be a community of speakers. In this sense, Wittgenstein saw no conceptual impossibility in a private language. One of Wittgenstein's main reasons for the public character of language in the first sense was the need of language-games to mediate language-world connections. But there are games that one can play alone, as Wittgenstein himself sometimes reminds us.

But doesn't Wittgenstein's emphasis on language-games - and the variety of different language-games - betray a belief in the social character of language or at least betray his rejection of his own earlier view of language as a mirror of the world? An acute answer was provided long ago by the acute Finnish philosopher Erik Stenius who correctly pointed out that there is no conflict between the idea of lan- 
guage as a picture and the idea of a variety of uses of language. We can play games with pictures. I can give you a picture as a move in several different language-games of the kind Wittgenstein envisaged. I can give it to you to tell what the world is like, but alternatively I can give it to you as a command to make sure that the world is as it is depicted by the pictures, or as a question whether the world is like it is in the picture, and so on. The real novelty of Wittgenstein's later position - to speak now in my own voice - is that according to him the very pictorial relationships are now created and maintained by those human activities that Wittgenstein called language-games. It is not just that we can play different games with the sentences of our language; the very descriptive meaning that enables us to do so is already constituted by certain language-games.

I believe that this idea of Wittgenstein's is not only a correct one but enormously fertile, and I have for a long time put my pen where my mouth is. For the idea of language as a mirror of nature, it implies so to speak both good news and bad news. It implies that we can speak of a correspondence between language and reality. But it also implies that possibility is not grounded on a structure shared by our sentences with the corresponding facts. There is no correspondence between language and the world grounded on the respective internal character of language and reality in their own right. As Wittgenstein once put it, the correspondence between language and reality, as everything metaphysical, lies in the use by language, that is, as I read Wittgenstein, in the language-games that constitute the semantical links between language and reality.

But this leads us straight to the third problem listed in the beginning of this essay. Can we really speak of the correspondence between our own language and reality in this same language - in the only language I understand, as Wittgenstein put it in the Tractatus? Is the semantics of our language expressible in that language? A crucial experiment is offered to us by the notion of truth. Is this concept ineffable after all? The list of philosophers who have maintained the ineffability of truth in our actual working language looks like the beginning of a veritable who's who in the philosophy of language: Frege, Russell, Wittgenstein, Tarski, and Quine, plus a large number of minor prophets. It is therefore - but not only for this contingent reason - of great interest to report to you that the outlook has dramatically changed in the last few years. The idea of truth, especially the idea of truth as correspondence, and even the idea of logic, has been put to a new light. 
There seems to be a fairly general agreement among philosophers that the basic part of contemporary logic known variously as quantification theory, predicate calculus or first-order logic is paradigm case of logic. For many philosophers and linguists, it is the logic. Once I expressed to a senior philosopher of language some doubts of the adequacy of first-order logic as the true Sprachlogik, that is, as the logic of our actual language. He stared at me with an expression of horror - mock horror, I hope - and said, "Nothing is sacred in philosophy any longer!" Yet there is a simple but profound reason why the received logic of quantification is, not wrong, but incomplete in the sense that it accomplishes only a part of its job description. To put it in personal terms, there is no point for you to buy (or to publish) any textbooks of logic until this fact is realised and corrected. The old ones do not tell you what our real basic logic is like.

In order to see this, imagine that your name is Dr. Zamenhoff and that you have been assigned by UNESCO the task of constructing a universal logical language for science and everyday life. What does such a language have to accomplish? Whatever else there is to be demanded of it, one thing is clear. In such a language, we must be able to express any possible pattern of dependence and independence between different variables. For of course we cannot a priori know that any such pattern is not exemplified in nature, society, mathematics or human thought. Without being able to represent all possible patterns of dependence and independence between variables we cannot claim that our logical language is a universal mirror of nature.

But how are dependence and independence between variables expressed between in a usual logical language? By the dependence or independence of the quantifiers on each other to which they are bound. And we are all told in introductory logic courses how these dependencies are indicated. They are indicated by the most important logical symbols, the brackets or parentheses (,). Such pairs of parentheses following a quantifier are said to indicate its scope. A quantifier depends on another one if and only if the former lies in the scope of the latter. But in the received Frege-Russell logic scopes are always nested. As a consequence, pairs of brackets can only express transitive and asymmetrical relations. For instance, branching or symmetrical quantifier structures cannot all be represented by their means. Hence many possible patterns of dependence and independence among quantifiers are impossible to express in a received logical language. For 
this reason the traditional Frege-Russell logic is inadequate as our general unrestricted basic logic.

This flaw is easy to correct. In principle, we could do so merely by liberalising the use of parentheses. A more convenient notation is obtained by introducing a new notation which as it were ad hoc exempts a quantifier from its dependence on another in whose (syntactical) scope it occurs. The result is a richer first-order logic which I have called independence-friendly (IF) first-order logic. This name has turned out to be a mistake, however. For one thing, I should not have been given it any particular epithet. For IF first-order logic is our unrestricted basic logic. It simply is the first-order logic. Instead, the traditional first-order logic ought to be renamed as dependencehandicapped first-order logic or, to be politically correct, independence-challenged logic. For another thing, it is not only possible to express more independencies between quantifiers in the new language than can be expressed in traditional first-order languages: it is also possible to express kinds of dependence that could not be expressed before. Hence the new logic might be called dependence-friendly logic as appropriately (or inappropriately) as independence-friendly one.

Under any name, the new logic is already promising new insights into several important subjects, including foundations of set theory, compositionality, parallel processing, and quantum logic. It represents an important breakthrough not only in logic, but in language theory and the logic of science. For the purposes of this essay, it is important for a reason which comes up when you try to define a truth predicate for a language in the very same language. For the purpose of doing so, one must be able to discuss the syntax (i.e. the purely formal aspects) of the language in question in the same language. Here an arithmetical language can serve as a clear-cut example. In such a language, this syntactical self-reference takes the form of Gödel numbering: One codes the expressions of this numerical language into suitable numbers. The result is a situation that can be compared with an amateur play. One can speak of the actors - and they can speak of each other - in two different roles, either as their everyday selves with their everyday names, families, careers and nationalities, or else as characters in a play with certain relationships to the other characters in the play and to the rest of the imaginary world of the play. In the same way, in a self-applied first-order arithmetical language one can speak of numbers as numbers, so to speak in their civilian role, but one can 
speak of them also as codifications of formulas. Neither in the case of actors nor in the case of numbers is there anything paradoxical in such double-entendre situation. Moreover, characters in a play can speak of denizens of the real world, including their own selves outside the play. (I once saw a movie about an imaginary tennis champion in which John McEnroe and Pancho Gonzales played themselves and discussed events in their actual life outside the movie.) Likewise - I almost said by the same token - a number which plays the role of an arithmetical sentence can say something about itself, for instance that it is unprovable.

However, one thing is clear: When you quantify over numbers in their two different roles, the quantifiers must be independent of each other. For otherwise we would make the same mistake as a small child might commit in thinking that there are dependencies between what happens in a play and what happens in real life.

But it turns out that these independencies are among those that cannot be expressed in the received first-order logic. Hence Tarski's undefinability result holds only because he has chosen as his basic language one which is based on the old received first-order logic. Or perhaps I can say that Tarski's impossibility theorem holds only because of certain subtle but important flaws in the logic of Frege and Russell that he was using. Accordingly, the general philosophical interest of Tarski's theorem is very small.

Indeed, when the received first-order logic is replaced by IF one, a truth-predicate automatically becomes definable. Contrary to a widespread opinion, the undefinability of truth in received first-order languages is not due to their being too strong, but to their being too weak in their expression power in that all possible patterns of dependence and independence between quantifiers cannot be expressed in them.

Even though these explicit results can be proved in the first place only for formal (but interpreted) first-order languages, there does not seem to be any doubt that they can be extended to suitable fragments of ordinary ("colloquial") language. As I once put it, in this way we can finally exorcise "Tarski's Curse" from our semantics.

What all this means for the theme of my paper should be clear. The gist of the mirroring relation mentioned there is the relation of a sentence to the fact that makes it true. And their relation is normally expressible in sufficiently strong languages without any hidden contradiction or paradox. Truth is not ineffable; "true" is no longer a fourletter word in language theory. Language can mirror the world. One 
can even argue that this mirroring possibly comes as it were free of charge. What I mean is this: The language-games which give a certain language its meaning is all we need for the purpose of defining a truth predicate for that language. Hence there is no folly in defining truth, as Davidson has claimed. The real folly is not to define it because the truth predicate comes to us gratis. This constitutes in fact a similarity between the IF truth predicates and the minimalist approaches to truth, even though the letter approaches have never been developed for enough to yield an explicit truth conditions.

At the same time, in speaking of a correspondence between language and the world we must heed the same warning as were registered earlier in this essay in connection with Wittgenstein's ideas. The kind of correspondence my truth predicate establishes between a sentence and a fact does not amount to any easily characterisable parallelism between the ingredients of a true sentence and the ingredients of the world that it is about. The definition of truth that IF logic naturally yields is truth of a sentence with the existence of a winning strategy for one of the players, the verifier, in certain games of verification and falsification. Even though in such games, called semantical games, each move is correlated with a logical constant in the sentence $S$ under examination, there is no simple correlation between the logical constants of $S$ and features (or its ingredients in general) of reality. The same constituent expression, e.g., a quantifier, can prompt several applications of a rule, and some of the expressions that must be used in a play of the game may not be subformulas of the initial sentences of the play. In this sense, the structure of language does not in any simple way mirror the structure of the world. And even to the extent that it does, the correlation between the two is not constituted by the intrinsic properties of either party, but by the human activities that I would call language-games if my first name were Ludwig. It is thus a matter of intellectual taste whether my treatment of truth should be labelled a correspondence theory of truth or not.

These results apply in the first place to language whose logical structure is made explicit. However, the same approach can be used in the study of the semantics of natural languages. Indeed, in my earlier work, I showed that in this way one can among other things obtain a much better theory of anaphora in natural languages than the better known competing ones. Moreover, the ideas and results I have reported have a great deal of relevance to semiotics. For instance, the semioticians who trace the ancestry of their ideas to Peirce might be 
intrigued to know that the game-theoretical interpretation of quantifiers that can be considered as a microcosm of the ideas expounded here was put forward explicitly and vigorously by Charles Sanders Peirce. Thus the interest of the issues and insights reviewed here extends way beyond any one approach to language and hopefully can serve as a means of integrating them.

\section{References $^{1}$}

Hilpinen, Risto 1983. On C. S. Peirce's theory of the proposition. In: Freeman, Eugene (ed.), The Relevance of Charles Peirce. La Salle (Illinois): The Hegeler Institute, 264-270.

Hintikka, Jaakko 1996a. Ludwig Wittgenstein: Half Truths and One-and-aHalf Truths. Dordrecht: Kluwer Academic.

- 1996b. The Principles of Mathematics Revisited. Cambridge: Cambridge University Press.

- 1998. Language, Truth and Logic in Mathematics. Dordrecht: Kluwer Academic.

— \& Kulas, Jack 1985. Anaphora and Definite Descriptions: Two Applications of Game Theoretical Semantics. Dordrecht: D. Reidel.

— \& Sandu, Gabriel 1993. On the Methodology of Linguistics. Oxford: Basil Blackwell.

— \& Sandu, Gabriel 1997. Game-theoretical semantics. In: Benthem J. van, Meulen A. ter, (eds.), Handbook of Logic and Language. Amsterdam: Elsevier, 361-410.

Hintikka, Merrill B.; Hintikka, Jaakko 1986. Investigating Wittgenstein. Oxford: Basil Blackwell.

\section{Язык как “зеркало природы”}

Как язык, который может использоваться для говорения о мире, репрезентирует (“отражает”) этот мир? И отражает ли? Одна из основных традиций в теории языка, включающая Фреге, Витгенштейна, Хайдеггера, Куайна и Рорти, отвечает на этот вопрос отрицательно.

The interpretation of Wittgenstein relied on here is expounded and documented in Hintikka \& Hintikka 1986, Hintikka 1996a. The new logic and some of its applications are explained in Hintikka 1996b, 1998, Hintikka \& Sandu 1997. Applications of related ideas to linguistics are found in Hintikka \& Kulas 1985, Hintikka \& Sandu 1993. C. S. Peirce's anticipation of game-theoretical semantics is explained in Hilpinen 1983. 


\section{Jaakko Hintikka}

Пробным является вопрос о возможности выражения в языке критических “отражающих" отношений, особенно понятия истины. Казалось, что негативный тезис Тарского закрыл проблему, но недавние примечательные исследования разрешили ее в пользу выражаемости истины. В то же время "отражаюшие" отношения не являются естественными, но формируются управляемой правилами человеческой деятельностыю наподобие языковых игр Витгеншттейна. Эти отношения, тем не менее, объективны, так как они зависят только от правил этих "игр", но не от идиосинкразии игроков. Оказывается, что для языка "истинностные игры" то же самое, что языковые игры, которые придают ему значение. Таким образом, значение и истина внутренне сплетены.

\section{Keel kui "looduse peegel"}

Kuidas keel, mida võib kasutada rääkimiseks maailmast, representeerib ("peegeldab") seda maailma? Ja kas üldse peegeldab? Üks peamisi keeletooria traditsioone (mille esindajateks on Frege, Wittgenstein, Heidegger, Quine ja Rorty), vastab sellele eitavalt. Proovikiviks on siin küsimus võimalusest väljendada keeles kriitilisi "peegeldavaid" suhteid, eriti tõe mõistet. Tundus, et Tarski negatiivne tees sulges probleemi, kuid hiljutised tähelepanuväärsed uurimused lahendasid selle tõe väljendumislikkuse kasuks. Samal ajal need "peegelduvad" suhted ei ole loomulikud, vaid kujunevad inimtegevuse reeglite läbi, sarnaselt Wittgensteini keelemängudele. Sellest hoolimata on need seosed objektiivsed, kuna nad sõltuvad ainult nende "mängude" reeglitest, aga mitte mängijate idiosünkraasiast. Selgub, et keele jaoks on "tõemängud" sama, mis tähendust omistavad keelemängud. Seega on tähendus ja tõde omavahel seesmiselt põimunud. 